\title{
Parental Style, Celebrity Endorsement and Product Packaging: A Qualitative Study of Purchase Intention of Children and Parents
}

\author{
SOHAIL SHAHZAD \\ Student of MBA (1.5) Marketing at the Institute of Management Sciences, Peshawar, Pakistan \\ Email: Sohail.siddiqui987@gmail.com \\ MOUDASSIR HABIB \\ Corresponding Author: Lecturer, Department of Management Sciences, FATA University \\ Email: m.habib@fu.edu.pk

\section{Dr. MUHAMMAD NOUMAN} \\ Associate Professor at Institute of Management Sciences Peshawar, Pakistan \\ Email: Muhammad.nouman@imscineces.edu.pk
}

\begin{abstract}
The purpose of this study is to investigate the effect of parental style, celebrity endorsement, and product packaging on purchase intention. This study also investigates the factors that affect the purchase intention of children and parents in confectionery products. Using findings from the literature review three research objectives were developed along with a theoretical framework. A qualitative research methodology is selected. The data is collected from parents and their children through semi-structured interview derived from literature. The data is analyzed qualitatively by using Dey's analysis framework. The parental style has more influence on children with reference to purchase intention in both general and in confectionery products. Celebrity is mostly the second or last priority in terms of both general and confectionery products. People are more towards product benefits and quality. Product packaging is the most attractive and important thing to change the customer's intentions. Parents and children both are attracted to the product with new, unique, shiny and colourful packaging.
\end{abstract}

Keywords: Advertisement, Parental Style, Celebrity Endorsement, Product Packaging, Purchase Intention, Confectionery Products, Children and Media.

\section{Introduction}

Advertisements for a product through different strategic medium play an important role in the purchase decision of customers. Manufacturers keep in mind certain assumptions before passing their ads on air such as product packaging and innovation in the product in terms of product quality and product benefits. Likewise, the purchase of confectionery products is also affected by the same marketing strategies. Watching ads for more than one hour affect the mindset of consumers regarding products. Advertisement helps in enhancing the sales of companies. Due to this, certain legislations are imposed in various countries on ads that are restricted to children are banned on some TV channels. Advertisements can be passed to consumers in many ways such as through electronic media, radios, print media and billboards. Currently, children usually watch TV for the purpose of watching cartoons or movies. Besides, there are various means of ads like event sponsorships, in-store advertisements and product packaging that is very significant promotional strategies for marketers. The products are usually decided on the basis of their packaging and 
other contrasting factors. These factors are obvious to customers because of their consistent ads on the air. The same process is adopted by almost all of the businesses as they spend the majority of their shares in advertisements which the financial managers think as it would enhance our sales by creating product differentiation in the mind of customers (Greuner, Kamerschen, \& Klein, 2000).

\section{Knowledge Gap}

This study is focusing on celebrity or non-celebrity endorsed advertisements, product packaging and parental style in the purchase of confectionery products both by parents and children. In this era, advertisement greatly influences customers because it delivers a message of worthy usage and emotional values about specific brands. This kind of message about the brand creates an encouraging strong bond with the customer. Numerous positive factors are ordered in such a manner that a viewer should fully understand the content and the message which the advertiser wants to convey. Hence, if all the factors are combined in an ordered manner and then the execution strategy is managed properly so then it can influence the consumer and the advertisement fulfills its objective (Schiffman \& Kanuk, 2000). The role of parental style, celebrity endorsement and product packaging have been considered an important aspect affecting the purchase intention of parents and children. Research has been carried out to signify the impact of parental style (Wisenblit Joseph, Priluck, \& Pirog Stephen, 2013), advertisement (Shabbir, 2016) and product packaging (Hill \& Tilley, 2002) on the purchase intention and consumption patterns of the children, however, these studies have been conducted in the developed countries and there is still gap in the literature to understand this complex phenomenon. Therefore, the main aim of this study is to signify the impact of celebrity endorsement, parental-style, and product-packaging on the purchase decisions of both parents and children. The respondents of the study are restricted to only 12 people from all over Peshawar, Pakistan.

\section{Literature Review}

An effective advertisement is one, which achieves the desired objective for the advertiser. Previous studies show that television advertising is the most powerful tool to have influence the attitude, behavior, and value of the viewers specifically children (Byrd-Bredbenner, 2002; Nash, Pine, \& Messer, 2009b). It motivates the viewers to start the purchasing process. TV advertising has a positive powerful effect on consumer's purchasing style and it can convey the consumer's message to the audience on a larger scale in a very efficient manner (Emma J. Boyland \& Halford, 2013). Once consumer purchase intention towards a product is constructed and the higher is the acquisition so the higher will be the temperament level of the consumer to buy that product (Schiffman \& Kanuk, 2000).

\section{TV Advertisement for Children}

According to Pakistan demographic index 2107, there is approximately one-third population of children mean form 0-15 and almost 50 percent of the children watch television who is below the age of 15 (NIPS, 2019). In recent times, television channels are in a competitive zone to advertise their products on TV. In order to gain such a competitive edge, they show what they are interested in and not what children want to watch or what they want. There are no laws by the government for this activity; neither the society nor the parents are making efforts to aware the children about this situation buy. According to Wiman and Newman (1989), the demands of children who watch television advertisements will be preferably high to those children who are not into television. In the United States, studies commissioned by television cable network found that approximately 43 percent of the purchases made by parents is due to the advertisement influence on their children (A. Caruana \& R. J. o. c. m. Vassallo, 2003). Children are more interested in cartoon characters and thus the advertisers use cartoon characters to and specific music so that they more attention to commercial broadcast (Raju \& Lonial, 1990). Emma J Boyland, Harrold, Kirkham, and Halford (2012) postulates that children's attention and intention greatly depend upon what they focus on, what they are watching alone or with some family members or friends of the same age. 


\section{Purchase Intention of Customer}

Purchase intention is the preference and choice of a customer to buy a specific product. Another viewpoint is that the customer will first evaluate the product and then buy it. The intention may change from time to time with the influences of price and perceived quality of the product and services, besides consumer's purchase intention is influenced by external and internal factors, which may influence the buying behavior of the consumer (Nayeem, 2012). Previous studies have mentioned five stages to select and purchase a product. These include awareness about the product, interest, knowledge, preference, persuasion, and purchase (Gretzel, Fesenmaier, \& O’leary, 2006; Kotler \& Armstrong, 2010). It is a common assumption among people that products with low price and simple packaging may be of high risk as compared to high priced and beautifully packed products. The positioning of the brand in the consumer's mind is a powerful tool because the brand is just a name and symbol at first sight. Hence, companies can make loyal customers and retaining their market share (Mirabi, Akbariyeh, \& Tahmasebifard, 2015).

\section{Purchase Intention of Children}

Children compare different brands to satisfy themselves, which can be a very difficult task to decide on a single product in such a huge variety (Nash, Pine, \& Messer, 2009a). Keeping taste and temperament, children choose a product and then they like products, which are similar to the one they have chosen. The more they watch TV, the more they know about products and also increase the intake of the food (Matheson, Killen, Wang, Varady, \& Robinson, 2004).

Branding is considered as one of the critical factors for creating and augmenting purchase intentions of the children and therefore food advertisement takes a branding approach (Connor, 2006) and television advertisement is thought to be very effective at developing strong brands (Heath, 2009).

In food advertisements (which mainly focus on children), the advertiser's animations play an important role and influence the children (Linn \& Golin, 2006). Their minds can be easily diverted towards the product. It is examined from different studies that on Sunday morning advertisements are more towards animations, moving pictures and cartoons, just to entertain the children and reach the product in their mind (Garretson \& Niedrich, 2004).

\section{Factors Influencing Purchase Intention of Children}

There are a number of factors, which influence customer's intentions while purchasing a product and it is mostly influenced by large external factors (Kotler, Keller, Ang, Tan, \& Leong, 2018).

\section{Celebrity Endorsement}

Nowadays most of the marketers employ celebrity endorsement in the selling of confectionary products (Madan, 2010). Most children have usually comprehended the intent to encourage when they reach eight years while after eleven (11) or twelve (12) years they develop a crucial knowledge of ads. Children ranging from nine years to twelve years and in between their teenagers are more probably devoted towards the messaging content and encouraged due to their attention and engagement in particular activities and based on that they put-forward for a product or proposition. Thus, ads for teens are more possibly demanding via their stylish and witty subtle and imagery messages. Apparently, celebrities act as role models because of their impact on various ads. Based on ads children identify themselves really close to the star being appeared in the advertisement (Katke, 2017).

There are numerous proofs that illustrate the celebrity endorsement role in ads and preferences of children for considering a product. According to (Brucks, Goldberg, \& Armstrong, 1986), the appearance of celebrities in various ads positively influence the purchasing behavior of children towards certain products. 
Additionally, celebrities are perceived by children as experts act in the subject of matter. Likewise, children from five to seven years positively perceive the food products via characters like Barney Rubble and Fred Flintstone. A product is perceived as acceptable and credible when such characters are introduced in ads for products (Atkin, 1980). Additionally, the study reported that this type of ads generally affects those kids who are habitual addicts of watching television. Similarly, children prefer a product when there is an endorsement of a celebrity in it (Bandyopadhyay, Kindra, \& Sharp, 2001).

According to Alsmadi (2006), different innovative ads styles are adopted by marketers to affect the consumer's behavior for brand choice and among these various accessible selections, the famous choice is the endorsement of celebrities in ads. Another study presented a model that is a function of several input parameters correlating the effectiveness of endorsement in making purchase decisions(Prasad \& Girdhar, 2005).

\section{Role of Parental Style}

Children attain skills and attitudes in a process of socialization with different factors of the society including market place. In this overall socialization process, parental influence is the most effective and persuasive one (A. Caruana \& R. Vassallo, 2003). In this context, the socialization orientation of the parents has been termed as parental style (Baumrind, 1968). Parental styles have been changing throughout the years. For instance, parental hostility versus warmth (also nurturance) was termed as authoritarian vs overprotective (Carlson, Grossbart, \& Stuenkel, 1992). Neeley and Coffey (2007)presented four types of parental styles that depend on the extents of authoritarianism and nurturing. Those four types are authoritarian (high authoritarian/ low nurturing), authoritative (high authoritarian/ high nurturing), neglecting (low authoritarian/ low nurturing) and permissive (low authoritarian/ high nurturing). Socialization studies for consumers used various types of parental-style to asses family consumption and communication. Those children who are nurturing usually depends on their parent more than neglecting ones who pay very less consideration to their whole children than those who are more protective and caring regarding the consumption of their children (Moore \& Moschis, 1978). Another study is on the basis of the low and high concept of social orientation styles of communication (Bakir, Rose, \& Shoham, 2005). The concept of orientation is related to those parents who have nurturing behavior while a social orientation is in favor of authoritarianism. Nurturing families urge debates leading to independent perspectives of children. Apparently, strict families are in favor of impartial thinking whilst controlling their behaviors of consumption. Neglecting families are perceived as they pay less attention to their children and hence negligibly affecting their children's consumption behavior. At times protective families assume obedience from their siblings(Bakir et al., 2005). Nurturing styles of parenting provokes their children in such a manner to buy whatever their parents suggest (Bao, Fern, \& Sheng, 2007). Styles of the parent also presented to affect parent's concerns for food ads, preference for regulating ads to their children (Carlson, Laczniak, \& Walsh, 2001).

\section{Product Packaging}

Packaging has been considered an important marketing strategy to target children segments in the marketing segmentation process. For instance, marketers use the concept of entertainment and fantasy to target children through the packaging of their products by describing their products as entertaining and fun (Kelly, Turner, \& McKenna, 2006). Packaging of the product no longer serves as a function of safety but the marketers are using packaging to influence the purchase decision of the children and also as an important element of branding (Ahmed, Ahmed, \& Salman, 2005).

Rettie and Brewer (2000, p. 59) define packaging as a "vehicle for communication and branding" and similarly packaging has also been described as a "silent salesman" (Hill \& Tilley, 2002, p. 767). Visuals and informational elements on packaging influence the purchase decision of the adults, however, due to the lower abilities of the children to process information, children assess products on the basis of visual ads 
(Ogba \& Johnson, 2010). Hill and Tilley (2002) conducted in-depth interviews with the children to determine the importance of packaging. Through discussion, it has been found that children have a justifiable preference to the visuals and characters on the product packaging which not only easily identifiable for them but also makes them realize the entertainment and fantasy factor while buying that product. Therefore, marketers consistently use visual and graphic characters on the product packaging to influence the purchase decisions of children. In addition to this, the color of the packaging also plays a central role as the packaging with bright colors has more chances of children's choice than others (Marshall, Stuart, \& Bell, 2006). In line with the concept of "eatertainment" by Roberts (2005), children respond to the food products not only on its nutritious value but for the fun or perceived entertainment to be enjoyed.

From the literature review, it is observed that the mostly factors such as celebrity endorsement, parental style, and product packaging have an influence on purchase intention. It has been observed that parental style and the product packaging is the most influential elements which affect the purchase intention of children in confectionery products. Mostly in general products, people get more inspired by celebrity endorsement and new packaging.

Celebrity endorsement indicates that product recognition and recall are related to celebrity endorsement. The advertisers try to absorb the customer emotionally with their product by showing influential celebrities in order to link the product with that specific celebrity. In children advertising, the advertiser mostly focuses on showing some specific cartoon characters.

In relation to parental style, the literature suggests that nurturing mothers are more attracted to the ads and they shift that information to their children while having a conversation in daily routine. Another strong element is product packaging which has a direct effect on both children and adults as consumers. Hence, in confectionery products, especially children are more attracted to the products that have attractive and catchy packaging.

\section{Research Questions}

Literature review suggests that the purchase intention of children is mostly influenced by three factors such as celebrity endorsement, parental and product packaging. On the basis of this, the following are three main questions.

1) How celebrity endorsement influences the purchase intention of parents and children for confectionery products?

2) How parental style influences the purchase intention of children for confectionery products?

3) How product packaging influences the purchase intention of children for confectionery products?

\section{Theoretical Framework}

On the basis of the above research questions, the following theoretical model is presented.

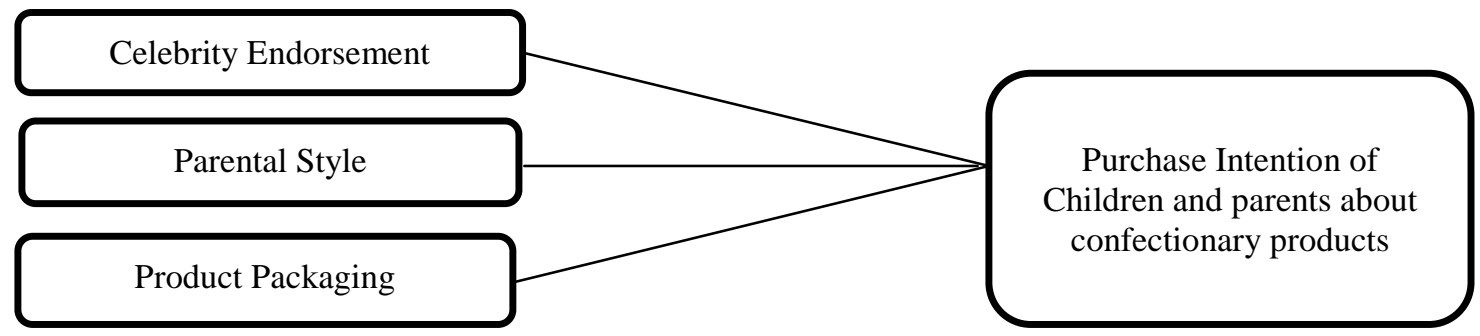

Fig 1: Theoretical Framework of the study 


\section{Research Methodology}

\section{Data Collection}

The data for this research is collected through the semi-structured interviews because the research topic and research questions are more focused on how, why and explain. The semi-structured interview is a purposeful discussion between the researcher and respondent which provides deep and rich information about the research problem and objectives (Creswell \& Creswell, 2017). Fifteen questions for the interview are developed from the literature review cited in the table below. Eight questions were asked from the parents and seven from the children regarding the purchase decision of the confectionery products.

\begin{tabular}{|l|l|l|}
\hline S.No. & \multicolumn{1}{|c|}{ Interview Elements } & \multicolumn{1}{c|}{ Literature } \\
\hline 01 & Purchase Intentions & (Calvert, 2008; Younus, Rasheed, \& Zia, 2015) \\
\hline 02 & Celebrity Endorsement & (Calvert, 2008) \\
\hline 03 & Product Packaging & (Dilogini \& Shivany, 2015; Shabbir, 2016) \\
\hline 04 & Parental style & (Moore \& Moschis, 1981; Wisenblit, Priluck, \& Pirog, 2013) \\
\hline
\end{tabular}

\section{Sample Selection and Size}

Unlike quantitative research, certain methods and rules to determine sample size are not clearly defined in qualitative research. Patton (2002, p. 243) describes as "there are no rules for sample size in qualitative inquiry. The sample size depends on what you want to know, the purpose of inquiry and what can be done with the available time and resources". In this study, qualitative data were collected from twelve respondents through semi-structured interviews in the city of Peshawar, Khyber PakhtunKhwa, Pakistan. Among the respondents six were parents and six were their children.

\section{Data Analysis}

In this study, the two frameworks will be used for data analysis. One is (Dey, 1993) the qualitative analysis framework. In this guide, collected data are coded and then categorized accordingly to make more sense of the data. A chronic problem of the qualitative study is that it is done primarily with words, not with numbers. Miles and Huberman (1992) argue that though words could also be cumbersome than numbers and as a result, the meaning of the data cannot be justifiably presented.

\section{Analysis and Discussion}

\section{Influence of Celebrity endorsement in advertisements}

Advertisements are subcategorized according to the different statuses like celebrity-endorsed and noncelebrity endorsed (P-Type Adv. Pur.P-Celeb; P-Type-Adv, Pur.p-Non-Celeb), that is linked with distinguished celebrity expertise with products (Celb-Ex- P-Int), likeability of celebrity with the product (Celb-Lik-I-PB).

A comprehensive interview is taken from all the participants. Most of the respondents preferred the quality and benefits of the product. Some of them also suggested that celebrity endorsement with the advertisements of products is highly preferable as compared to the products with whom the celebrity endorsement is not linked. The most popular bubble brand a celebrity-endorsed a brand is liked by a maximum number of children namely Boom Boom Bubble gum. From this act of customers, it can be drawn as the most important factor is the linkage of celebrity with the products in advertisements. 


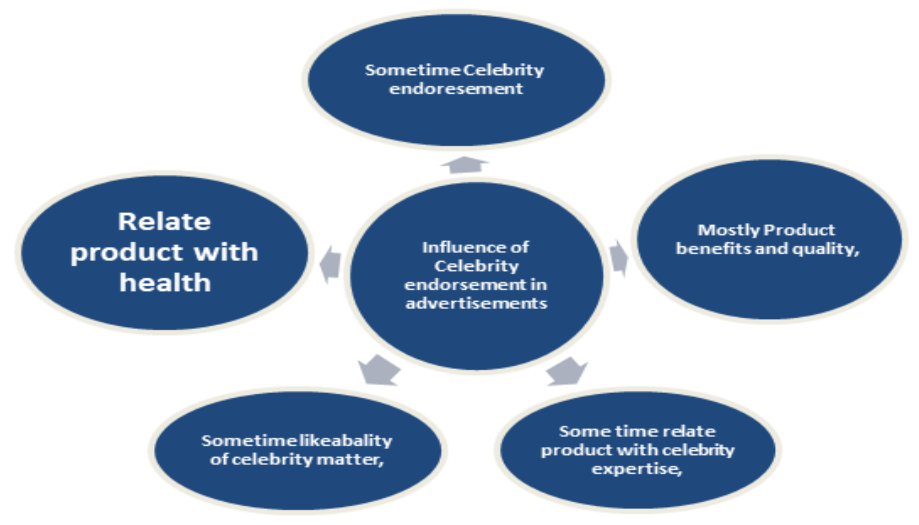

Fig 2: Celebrity endorsement influence

According to the discussion, it's analyzed that celebrity endorsement does matter but most people prefer celebrity as a second or last priority because people are more conscious about the product benefit and relate it with health. In terms of cartoon characters, children do recall the brand through a specific character but most of the time they cannot buy the product because of their parents. Likeability of a celebrity does matter in the purchase intention of the customer but again most preferably people are more towards the product benefits. If they like a celebrity and they recall a product but still the benefit comes first.

\section{Influence of Parental Style on Purchase Intention}

It has been observed that families and parents play a significant role in the purchasing process or pattern of their children. The parental style is a very diverse phenomenon, and for making it clear and obvious it has been spliced into six major categories. Those categories are child response and preference to child-feelings (Resp-CF), the considered wishes by parents (CW-UF-BF), freely talk and watching of television (CV-TV / $\mathrm{C}-\mathrm{TF}$ ), handling of children in unhealthy products (C-BPR-DS), impact on children buying behavior (BPPI/ OC) and the handling capacity of a situation when a product is liked (LP-PDL-HS).

Besides, the product brand is also an important and influential factor in confectionery products. In this regard parents aware of their children about the brand and health-related issues of a product. Other than confectionary products parents delegate the authority of purchase to their children such as clothes, shoes, toys, etc. Moreover, parents also allow their children to watch different TV channels; the reason for allowing them is to talk freely in front of their parents.

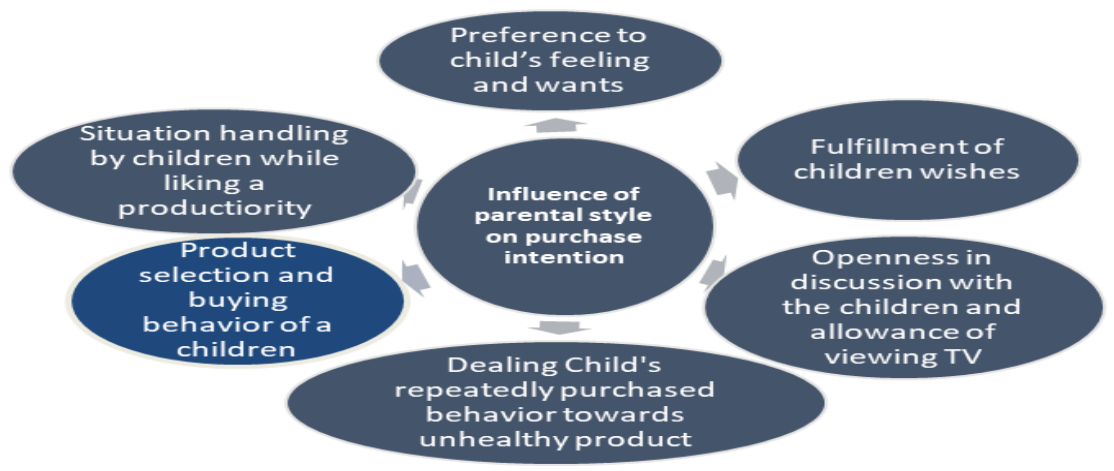

Fig 3: Parental style influence 
It has been analyzed from the interviews that parents are more authoritarian in terms of confectionery products because they prefer the product which is healthy for their children or at least which are not harmful. Almost every parent allows their children to share their thoughts with them in terms of products or general life. They allow them to watch TV for a certain time but again most of the parents were having a specific time for their children to watch TV and again specific channels are allowed to watch. Some children resist buying a product which is not good for their health so their parents deal with them in a diplomatic way to provide some other alternative product just to mold a child's mind from that specific unhealthy products.

\section{Influence Product Packaging on Purchase Intention of Children}

People are mostly attracted to those products that are unique and new in the market. Both children and parents are influenced by the new arrivals of the product in the market. So, for knowing the behaviors of participants, interviews were held from the parents and children to know about their perception and preferences regarding product packaging and innovative product entrants. Different questions were designed related to product packaging in order to know their buying behavior namely attraction of children by product packaging through promotional mediums (PP-Att/ Ad / PM), the preferences of children for new products (NDP-EBP), the choices of children in purchase of confectionery products (PP-SPA) and children buying behavior through ads and favorable word of mouth (SPOC/Ad/ C).

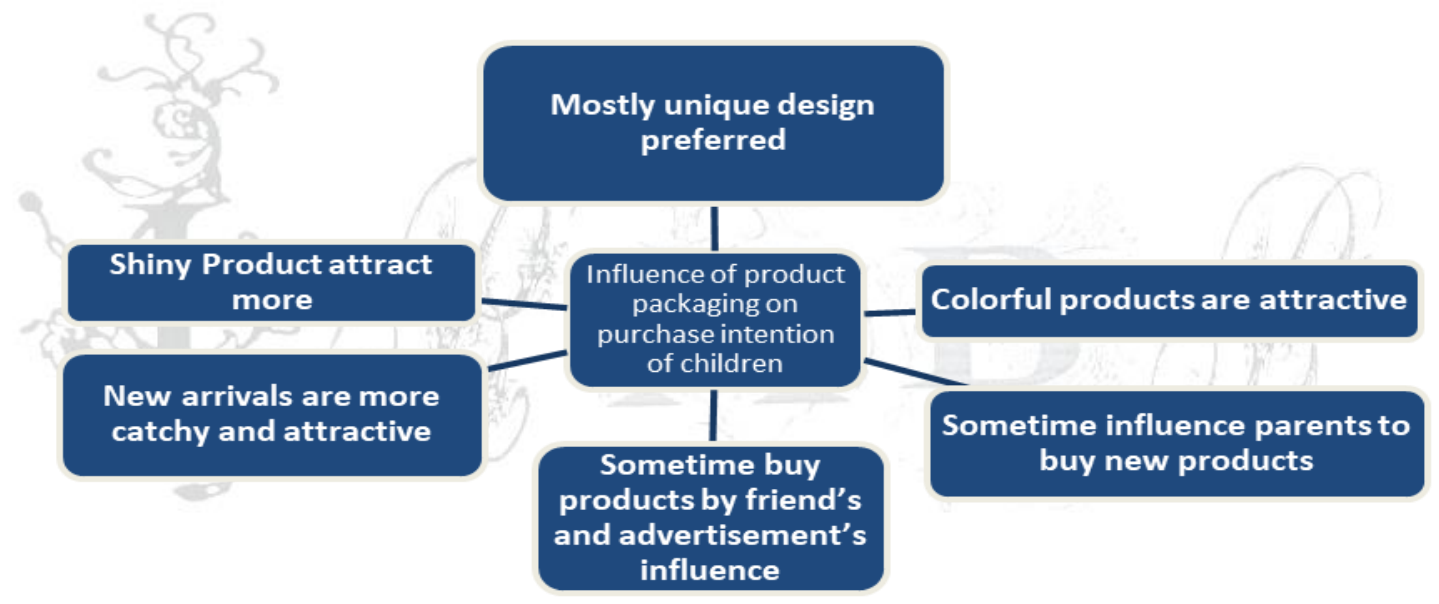

Fig 4: Product packaging influence

One of the participants notified that during buying the children prefer and buy those products that have a unique sort of packaging. That is either because of its advertisements or packaging but mostly they prefer new products.

It has been analyzed that product packaging is the most important factor for a marketer to grab the attention of their customer. In confectionary product children are more towards the product with unique, shiny and new packaging and almost all the parents stated that their children give more preference to the product in the shops which have new and unique sort of packaging. Parents are also more towards the product with unique packaging. They stated the example of the new arrival.

\section{Conclusion and Recommendations}

The main aim of the study was to investigate the factors that influence the purchase decisions of children and parents. For this purpose, three main elements are focused more such as parental style celebrity endorsement and product packaging. Semi-structured interviews were held from the respondents and it has 
been observed that children in the age limit of 8-13 buy the products that are celebrity endorsed. In Pakistan, parents play a major role in the purchase of confectionery products for their children. To be more specific authoritarian parental style is more implemented by parents to buy products for their children. Product packaging has a greater impact on the purchase decisions of customers.

Just three factors are studied and there are more factors which should be kept in mind in future studies. Furthermore, the area of study should be extended to the whole of Pakistan in future studies. It is recommended to the manufacturers that they have to manufacture goods that are positively associated with human health. The government should keep a check on the unauthorized and non-licensed manufacturers. The reason behind this is that nonlicensed companies are unable to monitor and regulated properly and due to this their products cannot be trusted easily.

\section{References}

Ahmed, A., Ahmed, N., \& Salman, A. (2005). Critical issues in packaged food business. British Food Journal, 107(10), 760-780.

Alsmadi, S. (2006). The Power of Celebrity Endorsement in Brand Choice Behavior: An Empirical Study of Consumer Attitudes. Journal of Accounting, Business Management 13.

Atkin, C. K. (1980). Effects of television advertising on children. Children the faces of television: Teaching, violence, selling 287-305.

Bakir, A., Rose, G. M., \& Shoham, A. (2005). Consumption communication and parental control of children's television viewing: a multi-rater approach. Journal of Marketing Theory Practice 13(2), 4758.

Bandyopadhyay, S., Kindra, G., \& Sharp, L. (2001). Is television advertising good for children? Areas of concern and policy implications. International Journal of Advertising, 20(1), 89-116.

Bao, Y., Fern, E. F., \& Sheng, S. (2007). Parental style and adolescent influence in family consumption decisions: An integrative approach. Journal of Business Research, 60(7), 672-680.

Baumrind, D. (1968). Authoritarian vs. authoritative parental control. Adolescence, 3(11), 255.

Boyland, E. J., \& Halford, J. C. G. (2013). Television advertising and branding. Effects on eating behaviour $\begin{array}{lllll}\text { and } & \text { food } & \text { 236-241. }\end{array}$ doi:https://doi.org/10.1016/j.appet.2012.01.032

Boyland, E. J., Harrold, J. A., Kirkham, T. C., \& Halford, J. C. (2012). Persuasive techniques used in television advertisements to market foods to UK children. Appetite, 58(2), 658-664.

Brucks, M., Goldberg, M. E., \& Armstrong, G. M. (1986). Children's cognitive responses to advertising. ACR North American Advances.

Byrd-Bredbenner, C. (2002). Saturday morning children's television advertising: a longitudinal content analysis. Family and Consumer Sciences Research Journal, 30(3), 382-403.

Calvert, S. L. (2008). Children as consumers: Advertising and marketing. The future of children 18(1), 205234.

Carlson, L., Grossbart, S., \& Stuenkel, J. K. (1992). The role of parental socialization types on differential family communication patterns regarding consumption. Journal of Consumer Psychology, 1(1), 31-52.

Carlson, L., Laczniak, R. N., \& Walsh, A. (2001). Socializing children about television: An intergenerational study. Journal of the Academy of Marketing Science, 29(3), 276-288.

Caruana, A., \& Vassallo, R. (2003). Children's perception of their influence over purchases: the role of parental communication patterns. Journal of consumer marketing, 20(1), 55-66.

Caruana, A., \& Vassallo, R. J. o. c. m. (2003). Children's perception of their influence over purchases: the role of parental communication patterns. Journal of consumer marketing, 20(1), 55-66.

Connor, S. M. (2006). Food-related advertising on preschool television: building brand recognition in young viewers. Pediatrics, 118(4), 1478-1485.

Creswell, J. W., \& Creswell, J. D. (2017). Research design: Qualitative, quantitative, and mixed methods approaches: Sage publications. 
Dey, I. (1993). Qualitative Data Analysis: A User-Friendly Guide: Routledge.

Dilogini, K., \& Shivany, S. (2015). Television Advertisements and Children's Behavior: Parents' Experiences Base Study in the Post-War Context. ACADEMICIA, 5(5).

Garretson, J. A., \& Niedrich, R. W. (2004). Spokes-characters: Creating character trust and positive brand attitudes. Journal of advertising 33(2), 25-36.

Gretzel, U., Fesenmaier, D. R., \& O'leary, J. T. (2006). The transformation of consumer behaviour. In Tourism business frontiers (pp. 31-40): Routledge.

Greuner, M. R., Kamerschen, D. R., \& Klein, P. G. (2000). The competitive effects of advertising in the us automobile industry, 1970-94. International Journal of the Economics of Business 7(3), 245-261.

Heath, R. (2009). Emotional engagement: How television builds big brands at low attention. Journal of advertising research 49(1), 62-73.

Hill, H., \& Tilley, J. (2002). Packaging of children's breakfast cereal: manufacturers versus children. British Food Journal, 104(9), 766-777.

Katke, K. (2017). Role of child persuasive technique in family buying decision. International Journal of Research in Social Sciences 7(1), 36-44.

Kelly, J., Turner, J. J., \& McKenna, K. (2006). What parents think: children and healthy eating. British Food Journal, 108(5), 413-423.

Kotler, P., \& Armstrong, G. (2010). Principles of marketing: Pearson education.

Kotler, P., Keller, K. L., Ang, S. H., Tan, C.-T., \& Leong, S. M. (2018). Marketing management: an Asian perspective: Pearson.

Linn, S., \& Golin, J. (2006). Beyond commercials: How food marketers target children. Loy. LAL Rev., 39, 13.

Madan, R. (2010). Celebrity endorsement: A marketing strategy. Internacional Journal of Marketing Management Research 1(1), 82-89.

Marshall, D., Stuart, M., \& Bell, R. (2006). Examining the relationship between product package colour and product selection in preschoolers. Food quality preference 17(7-8), 615-621.

Matheson, D. M., Killen, J. D., Wang, Y., Varady, A., \& Robinson, T. N. (2004). Children's food consumption during television viewing. The American journal of clinical nutrition, 79(6), 1088-1094.

Miles, M. B., \& Huberman, A. M. (1992). Qualitative data analysis. 2: Thousand Oaks.

Mirabi, V., Akbariyeh, H., \& Tahmasebifard, H. (2015). A study of factors affecting on customers purchase intention. Journal of Multidisciplinary Engineering Science Technology 2(1).

Moore, R. L., \& Moschis, G. P. (1978). Teenagers' reactions to advertising. Journal of advertising, 7(4), 24-30.

Moore, R. L., \& Moschis, G. P. (1981). The role of family communication in consumer learning. Journal of Communication 31(4), 42-51.

Nash, A. S., Pine, K. J., \& Messer, D. J. (2009a). Television alcohol advertising: do children really mean what they say? British Journal of Developmental Psychology 27(1), 85-104.

Nash, A. S., Pine, K. J., \& Messer, D. J. (2009b). Television alcohol advertising: do children really mean what they say? British Journal of Developmental Psychology, 27(1), 85-104.

Nayeem, T. (2012). Cultural influences on consumer behaviour. International journal of Business management 7(21), 78 .

Neeley, S. M., \& Coffey, T. (2007). Understanding the" four-eyed, four-legged" consumer: a segmentation analysis of US moms. Journal of Marketing Theory Practice 15(3), 251-261.

NIPS. (2019). Pakistan Demographic and Health Survey. Retrieved from Islamabad

Ogba, I.-E., \& Johnson, R. (2010). How packaging affects the product preferences of children and the buyer behaviour of their parents in the food industry. Young Consumers, 11(1), 77-89.

Patton, M. (2002). Qualitative research and evaluation methods.,(Sage Publications: Thousand Oaks, CA). In: CA.

Prasad, S. B., \& Girdhar, R. (2005). SP Gupta (2005). Elementary Statistical Methods," New Delhi: Sultan Chand Sons

Raju, P. S., \& Lonial, S. C. (1990). Advertising to Children: Findings and Implications. Current Issues and Research in Advertising, 12(1-2), 231-274. doi:10.1080/01633392.1990.10504953 
Rettie, R., \& Brewer, C. (2000). The verbal and visual components of package design. Journal of product brand management 9(1), 56-70.

Roberts, M. (2005). Parenting in an obesogenic environment. Journal of Research for Consumers (9), 1.

Schiffman, L. G., \& Kanuk, L. L. (2000). Consumer behavior, $7 *$ edition. In: Prentice Hall, Upper Saddle River.

Shabbir, M. (2016). The Impact of Advertisement on Buying Behavior of the Children. Arabian Journal of Business Management Review 6(4), 1-10.

Wiman, A. R., \& Newman, L. M. (1989). Television advertising exposure and children's nutritional awareness. Journal of the Academy of Marketing Science 17(2), 179-188.

Wisenblit Joseph, Z., Priluck, R., \& Pirog Stephen, F. (2013). The influence of parental styles on children's consumption. Journal of consumer marketing, 30(4), 320-327. doi:10.1108/JCM-02-2013-0465

Wisenblit, J. Z., Priluck, R., \& Pirog, S. F. (2013). The influence of parental styles on children's consumption. Journal of Consumer Marketing 30(4), 320-327.

Younus, S., Rasheed, F., \& Zia, A. (2015). Identifying the Factors Affecting Customer Purchase Intention. Global Journal of Management Business Research.

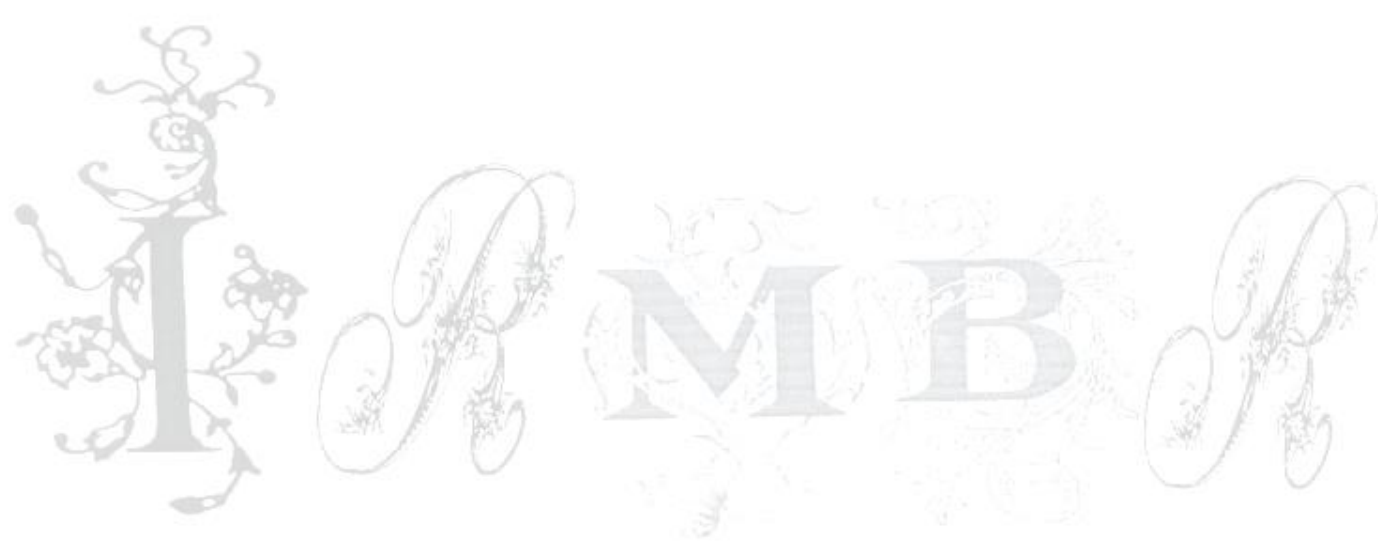

